\title{
SISTEM INFORMASI PERENCANAAN PENGADAAN OBAT DI DINAS KESEHATAN KABUPATEN BOYOLALI
}

\author{
Erni Rahmawatie ${ }^{1}$, Stefanus Santosa ${ }^{2}$ \\ ${ }^{1}$ Program Pascasarjana, Universitas Dian Nuswantoro \\ ${ }^{2}$ Politeknik Negeri Semarang \\ ${ }^{1}$ erni_rahmawatie@yahoo.co.id \\ ${ }^{2}$ stefanus_Santosa@yahoo.co.id
}

Abstrak: Obat memegang peran yang penting dalam pelayanan kesehatan karena obat merupakan salah satu sarana untuk meningkatkan derajat kesehatan. Dinas Kesehatan Kabupaten Boyolali Propinsi Jawa Tengah merupakan dinas yang salah satu tugasnya adalah merencanakan, melaksanakan, mengarahkan, mengawasi, dan mengendalikan bidang kesehatan sesuai kebijakan pemerintah daerah. Setiap bulannya salah satu program Dinas Kesehatan Kabupaten Boyolali adalah memantau kegiatan setiap puskesmas berkaitan dengan 10 penyakit terbanyak, trend penyakit, stok obat, dan penggunaan obat. Data tersebut menjadi acuan untuk membantu pemerintah daerah dalam mendukung keputusan pemerintah dalam perencanaan pengadaan obat. Penelitian ini bertujuan untuk membuat sistem yang mampu menghasilkan informasi yang dapat mendukung perencanaan pengadaan obat oleh pemerintah daerah. Metode pengembangan sistem yang digunakan dalam penelitian ini adalah SDLC (System Development Live Cycle).

Kata kunci: Sistem Informasi, Perencanaan, Pengadaan Obat.

Abstract: Drug holds an important role in health care. District Health Office Boyolali, Central Java Province has a duty to plan, implement, direct, supervise, and control the health sector according local government programs. Boyolali District Health Office has the task of monitoring the activities of each health center associated with 10 diseases, disease trends, stocks of drugs, and drug use. The data is used as reference for planning the procurement of drugs. This study aims to create a system that is able to generate information that can support drug procurement planning by local governments. This research uses SDLC systems development method (System Development Live Cycle).

Keyword: Information System, Planning, Procurement of Drugs.

\section{PENDAHULUAN}

Obat memegang peran yang penting dalam pelayanan kesehatan karena obat merupakan salah satu sarana untuk meningkatkan derajat kesehatan [1]. Obat merupakan salah satu komponen penting dalam pelayanan kesehatan sehingga ketersediaannya harus terjamin dalam jumlah dan jenis yang cukup sesuai dengan kebutuhan, secara tepat waktu, merata, dan berkesinambungan. Biaya obat merupakan bagian terbesar dari anggaran kesehatan. Di beberapa negara maju berkisar antara $10 \%$ - 15\% dari anggaran kesehatan dan di negara berkembang biaya ini lebih besar lagi antara 35\% $66 \%$ [2].

Aspek terpenting dari pelayanan farmasi adalah mengoptimalkan penggunaan obat. Ini harus termasuk perencanaan untuk menjamin ketersediaan, keamanan, dan keefektifan penggunaan obat [3].

Menurut Arnawilis salah satu faktor penting dalam perencanaan obat adalah pemakaian obat pada periode sebelumnya [4]. Perencanaan obat di Dinas Kesehatan Kabupaten Boyolali dilakukan berdasarkan metode konsumsi. Besarnya stok akhir obat menjadi dasar pengadaan obat karena dari stok akhir tidak saja diketahui jumlah dan jenis obat yang diperlukan, tetapi juga diketahui percepatan pergerakan obat, sehingga kita dapat menentukan obat-obat yang bergerak cepat (laku keras) agar dapat disediakan lebih banyak. Di 
Dinas Kesehatan Kabupaten Boyolali pada perhitungan stok akhir, sering terjadi ketidaksesuaian data antara pencatatan manual dengan data fisik, sehingga menyulitkan penetapan stok. Akibatnya pemesanan atau pembelian obat secara cito (obat yang tidak terencana yang harus segera diadakan) tidak dapat dihindari [5].

Kekosongan obat yang terjadi adalah akibat dari proses perencanaan, bukan akibat dari proses pengadaan. Untuk menghindari terjadinya stok kosong, maka harus dilakukan perencanaan yang lebih teliti sehingga tidak terjadi kekosongan obat di satu sisi dan kelebihan beberapa item obat di pihak lain [6].

Perencanaan Pengadaan obat memiliki 2 metode, yaitu metode konsumsi dan metode epidemiologi. metode konsumsi merupakan metode perencanaan berdasarkan atas analisis konsumsi logistik periode sebelumnya [7] sedangkan metode epodemiologi merupakan metode perencanaan berdasarkan atas analisis jumlah kasus penyakit pada periode sebelumnya. Jumlah kasus ini tergantung dari jumlah kunjungan, bor/los (hari perawatan) frekuensi penyakit dan standar pengobatan [8].

Kelebihan / Kekurangan Metode Konsumsi dan Metode Epidemiologi [9] tercantum pada tabel 1 berikut ini.

Tabel 1. Kelebihan / Kekurangan Metode Konsumsi dan Metode Epidemiologi

\begin{tabular}{|c|c|c|}
\hline Metode & Kelebihan & Kekurangan \\
\hline \multirow{3}{*}{ Konsumsi } & $\begin{array}{lr}\text { Tidak } & \text { dibutuhkan } \\
\text { data } & \text { morbiditas } \\
\text { dan } & \text { standar } \\
\text { pengobatan }\end{array}$ & $\begin{array}{l}\text { Data konsumsi } \\
\text { obat } \\
\text { Kontak dengan } \\
\text { pasien sulit }\end{array}$ \\
\hline & $\begin{array}{l}\text { Perhitungan lebih } \\
\text { sederhana }\end{array}$ & $\begin{array}{ll}\text { Tidak dapat } \\
\text { dijadikan dasar } \\
\text { pengkajian } \\
\text { penggunaan obat }\end{array}$ \\
\hline & $\begin{array}{ll}\text { Dapat } & \text { diandalkan } \\
\text { jika } & \text { pencatatan } \\
\text { baik } & \end{array}$ & $\begin{array}{lr}\text { Tidak } & \text { dapat } \\
\text { diandalkan } & \\
\text { apabila } & \text { terjadi } \\
\text { perubahan } & \text { pola } \\
\text { penyakit } & \end{array}$ \\
\hline
\end{tabular}

\begin{tabular}{|c|c|c|}
\hline \multirow{3}{*}{ Epidemiologi } & $\begin{array}{l}\text { Data konsumsi } \\
\text { tidak dibutuhkan }\end{array}$ & $\begin{array}{l}\text { Perlu waktu dan } \\
\text { tenaga } \quad \text { yang } \\
\text { banyak }\end{array}$ \\
\hline & $\begin{array}{lr}\text { Dapat digunakan } \\
\text { untuk pengkaji } \\
\text { pola pengobatan }\end{array}$ & $\begin{array}{l}\text { Ada penyakit } \\
\text { yang tidak tercatat }\end{array}$ \\
\hline & $\begin{array}{l}\text { Mendorong } \\
\text { melakukan } \\
\text { pancatatan } \\
\text { morbiditas }\end{array}$ & $\begin{array}{lr}\text { Pola } & \text { penyakit } \\
\text { tidak } & \text { sama, } \\
\text { khusus } & \text { wabah dan } \\
\text { variasi } & \text { obat lebih } \\
\text { luas }\end{array}$ \\
\hline
\end{tabular}

Metode konsumsi yang bersifat reaktif ternyata tidak mengatasi masalah stok obat karena pengadaan dilakukan bila ada kebutuhan.

Perencanaan Pengadaan Obat menggunakan metode konsumsi kurang sesuai dengan kebutuhan serta tidak dapat dijadikan dasar pengkajian penggunaan obat sehingga sering terjadi kekurangan stok obat pada gudang farmasi Dinas Kesehatan Kabupaten Boyolali.

Pendekatan yang telah dilakukan melalui Sistem Pendukung Keputusan juga tidak serta merta menyelesaikan masalah. Hasil kajian terhadap Sistem Pendukung Keputusan Perencanaan Pengadaan Obat berdasarkan ABC indeks kritis menunjukkan bahwa metode perhitungan berdasarkan $\mathrm{ABC}$ indeks kritis hanya digunakan untuk melihat jenis kekritisan obat yang jumlah jenis obatnya sudah diketahui. Dalam menentukan Perencanaan Pengadaan obat masih dibutuhkan metode perhitungan perencanaan pengadaan obat serta bentuk penyajian data yang lengkap dan disertai grafik.

Metode epidemologi yang bersifat proaktif memiliki peluang yang lebih besar untuk menyelesaikan masalah stok obat, namun juga terdapat unsur ketidakpastian di dalamnya.

Berdasarkan masalah tersebut di atas, maka ditetapkan tujuan penelitian sebagai berikut.

a. Terbentuknya Sistem Informasi Perencanaan Pengadaan Obat dengan menggunakan metode perhitungan gabungan antara metode konsumsi 
dengan metode epidemiologi di Dinas

Kesehatan Kabupaten Boyolali.

b. Diperolehnya kemudahan dalam menampilkan data melalui model Sistem Informasi Perencanaan Pengadaan Obat dengan menggunakan DevExpress Pivot Table dan grafik.

Bila tujuan tersebut tercapai maka penelitian ini diharapkan dapat membantu pihak rumaha sakit dalam melakukan perencanaan pengadaan obat untuk menjamin ketersediaan obat dalam arti harus menjamin bahwa obat yang diseleksi atau dipilih benar-benar memiliki manfaat terapi yang jauh lebih besar dibandingkan risikonya, serta merupakan obat terbaik di antara kompetitornya. Selain itu perkiraan perencanaan pengadaan obat mendekati kebenaran atau persentase ketersediaan obat sesuai kebutuhan.

Bagi Pengembangan IPTEK penelitian ini menyumbangkan model sistem informasi pengadaan obat dengan pendekatan gabungan antara metode konsumsi dan metode epidemiologi dengan menggunakan DevExpress Pivot Table dan grafik.

\section{LANDASAN TEORI}

\section{A. Konsep Dasar Sistem Informasi}

Sistem informasi adalah suatu sistem dalam suatu organisasi yang mempertemukan kebutuhan pengolahan transaksi harian yang mendukung fungsi operasi organisasi yang bersifat manajerial dengan kegiatan strategi dari suatu organisasi untuk dapat menyediakan kepada pihak luar tertentu dengan informasi yang diperlukan untuk pengambilan keputusan.

Sistem informasi dalam suatu organisasi dapat dikatakan sebagai suatu sistem yang menyediakan informasi bagi semua tingkatan dalam organisasi tersebut kapan saja diperlukan. Sistem ini menyimpan, mengambil, mengubah, mengolah dan mengkomunikasikan informasi yang diterima dengan menggunakan sistem informasi atau peralatan sistem lainnya [10].

B. Kemampuan Sistem Informasi Kemampuan yang dimiliki oleh sistem informasi, antara lain :

1. Melaksanakan komputasi numerik, bervolume besar dengan kecepatan tinggi

2. Menyimpan informasi dalam jumlah besar ke dalam ruang yang kecil dan mudah diakses

3. Menyajikan informasi dengan jelas

4. Meng-otomatisasi proses-proses yang manual

5. Menyediakan komunikasi dalam dan antarorganisasi yang murah, akurat, dan cepat.

\section{Kebutuhan Sistem Informasi}

Semua organisasi membutuhkan aliran informasi yang membantu manajer untuk mengambil bermacam keputusan yang dibutuhkan. Aliran informasi ini diatur dan diarahkan dalam suatu sistem informasi. Sistem informasi berperan dalam proses pengambilan keputusan operasional harian sampai perencanaan jangka panjang.

Sebelum komputer ada, sistem informasi sudah menjadi kebutuhan organisasi. Ini berarti sistem informasi tidak selamanya berbasis komputer. Namun dengan berkembangnya fungsi komputer, sistem informasi saat ini umumnya didukung penuh oleh komputer. Dengan demikian istilah sistem informasi lebih sering berarti sistem informasi berbasis komputer. Sistem informasi berbasis komputer mempunyai 6 bagian: hardware, software, data/informasi, prosedur, komunikasi, dan orang. SI ditentukan dalam perusahaan bergantung pada sifat dan struktur bisnisnya. Ini berarti SI bersifat modifikatif terhadap kebutuhan organisasi. Komponen prosedur dalam SI berkaitan 
dengan prosedur manual dan prosedur berbasis komputer serta standar untuk mengolah data menjadi informasi yang berguna. Suatu prosedur adalah urutan langkah yang dilakukan untuk menyelesaikan satu atau lebih aktifitas pengolahan informasi. Pengolahan informasi ini dapat dikerjakan dengan pengguna, atau kombinasi pengguna dan staff TI. Suatu bisnis terdiri dari berbagai macam prosedur yang digabungkan secara logis untuk membentuk suatu sistem.

Sebagai contoh sistem yang umumnya ada dalam suatu organisasi adalah sistem penggajian, personalia, akuntansi, dan gudang. Data mengalir dari bermacam sumber seperti : konsumen yang membeli produk atau layanan, penjual yang menyediakan barang, bank, agen pemerintah, dan agen asuransi. Sistem informasi membantu organisasi mengolah data tersebut menjadi informasi yang lengkap dan berguna.

Contoh kasus: Sistem informasi dalam Ekonomi Global pada Boehringer Ingelheim Jerman. Boehringer Ingelhiem adalah satu dari 20 perusahaan farmasi terbesar di dunia. Dengan pendapatan US\$7.6 juta dan 32.000 pegawai di 60 negara, perusahaan ini memiliki beberapa segmen seperti manufaktur dan pemasaran obat, produk industri dan produk kesehatan hewan. Dengan ukuran yang begitu besar manajemen merasakan kesulitan untuk mengambil keputusan berdasarkan informasi yang mengalir. Makin besar perusahaan, makin lambat aliran informasi [11].

\section{Komponen Sistem Informasi}

Sistem informasi terdiri dari komponenkomponen yang disebut blok bangunan (building blok), yang terdiri dari komponen input, komponen model, komponen output, komponen teknologi, komponen hardware, komponen software, komponen basis data, dan komponen kontrol.
Semua komponen tersebut saling berinteraksi satu dengan yang lain membentuk suatu kesatuan untuk mencapai sasaran. [11]

\section{Komponen input}

Input mewakili data yang masuk ke dalam sistem informasi. Input di sini termasuk metode dan media untuk menangkap data yang akan dimasukkan, yang dapat berupa dokumen dokumen dasar.

2. Komponen model

Komponen ini terdiri dari kombinasi prosedur, logika, dan model matematik yang akan memanipulasi data input dan data yang tersimpan di basis data dengan cara yang sudah ditentukan untuk menghasilkan keluaran yang diinginkan

\section{Komponen output}

Hasil dari sistem informasi adalah keluaran yang merupakan informasi yang berkualitas dan dokumentasi yang berguna untuk semua pemakai sistem.

\section{Komponen teknologi}

Teknologi merupakan "tool box” dalam sistem informasi. Teknologi digunakan untuk menerima input, menjalankan model, menyimpan dan mengakses data, menghasilkan dan mengirimkan keluaran, dan membantu pengendalian dari sistem secara keseluruhan.

\section{Komponen hardware}

Hardware berperan penting sebagai suatu media penyimpanan vital bagi sistem informasi. Yang berfungsi sebagai tempat untuk menampung database atau lebih mudah dikatakan sebagai sumber data dan informasi untuk memperlancar dan mempermudah kerja dari sistem informasi.

\section{Komponen software}

Software berfungsi sebagai tempat untuk mengolah,menghitung dan memanipulasi data yang diambil dari hardware untuk menciptakan suatu informasi. 
7. Komponen basis data

Basis data (database) merupakan kumpulan data yang saling berkaitan dan berhubungan satu dengan yang lain, tersimpan di perangkat keras komputer dan menggunakan perangkat lunak untuk memanipulasinya. Data perlu disimpan dalam basis data untuk keperluan penyediaan informasi lebih lanjut. Data di dalam basis data perlu diorganisasikan sedemikian rupa supaya informasi yang dihasilkan berkualitas. Organisasi basis data yang baik juga berguna untuk efisiensi kapasitas penyimpanannya. Basis data diakses atau dimanipulasi menggunakan perangkat lunak paket yang disebut DBMS (Data Base Management System).

\section{Komponen Kontrol}

Banyak hal yang dapat merusak sistem informasi, seperti bencana alam, api, temperatur, air, debu, kecurangan - kecurangan, kegagalan kegagalan sistem itu sendiri, ketidak efisienan, sabotase dan lain sebagainya. Beberapa pengendalian perlu dirancang dan diterapkan untuk meyakinkan bahwa hal - hal yang dapat merusak sistem dapat dicegah ataupun bila terlanjur terjadi kesalahan - kesalahan dapat langsung cepat diatasi.

\section{METODE PENELITIAN}

Metode perencanaan pengadaan obat terdiri dari metode konsumsi dan epidemiologi. Adapun Data yang dibutuhkan dalam perhitungan kebutuhan dengan metode epidemiologi adalah :

1. Kasus penyakit

2. Jumlah setiap kasus periode sebelumnya

3. Standar diagnosa dan terapi
a. Jenis obat yang digunakan
b. Dosis obat yang digunakan
c. Lamanya pengobatan

4. Formularium
Langkah-langkah Perhitungan

Metode

Epidemiologi:

1. Buat format data penyakit

2. Hitung jumlah penggunaan obat

3. Hitung jumlah kebutuhan

- Jumlah Obat yang digunakan (jumlah obat yang digunakan)

- Hitung jumlah pemakaian rata - rata = jumlah obat yang digunakan / jumlah hari kerja

- Stok pengamanan obat yang selalu harus tersedia bila terjadi peningkatan pasien, biasanya stok pengaman berkisar $10-20 \%$. diambil saja $10 \%$ jadi stok pengaman adalah Stok Pengaman $=10 \% * \mathrm{jml}$ pemakaian obat

- Waktu tunggu yang digunakan adalah $2-3$ hari, jadi kalau diambil 3 hari tunggu maka waktu tunggu $=3 *$ jumlah pemakaian rata - rata

- Hitung Jumlah kebutuhan periode kedepan dengan memperhatikan kenaikan kunjungan $=$ ( Jumlah Obat yang digunakan + Stok Pengaman + waktu tunggu ) - Sisa Stok.

4. Hitung jumlah pesanan $=$ jumlah kebutuhan (Sisa - obat rusak).

Data yang diperlukan dalam perhitungan Kebutuhan dengan metode konsumsi:

1. Buku defakta ( buku catatan logistik yang tidak dapat dipenuhi)

2. Permintaan dari bagian

3. Standar (Formularium/DEON)

4. Catatan jumlah kunjungan pasien minimal 2 periode sebelumnya

5. Catatan lead time (waktu pemesanan dibandingkan dengan waktu barang datang)

6. Catatan barang rusak dari setiap item logistik 
7. Catatan barang yang kadarluarsa dari setiap item logistik

8. Catatan stok pengaman

Langkah Perhitungan metode konsumsi adalah:

1. Tentukan periode perencanaan

2. Buat dan isi format mutasi barang

3. Hitung jumlah kebutuhan (sama dengan perhitungan jumlah kebutuhan pada metode epidemiologi di atas)
4. Hitung jumlah pesanan:

Jumlah pesanan $=$ jumlah kebutuhan $-($ Sisa yang rusak).

Berdasarkan pendekatan hibrid metode Konsumsi dan Epidemiologi tersebut ditentukanlah strategi dan tahapan yang digunakan dalam penelitian ini untuk mencapai tujuan yang diharapkan seperti terlihat pada diagram berikut ini.

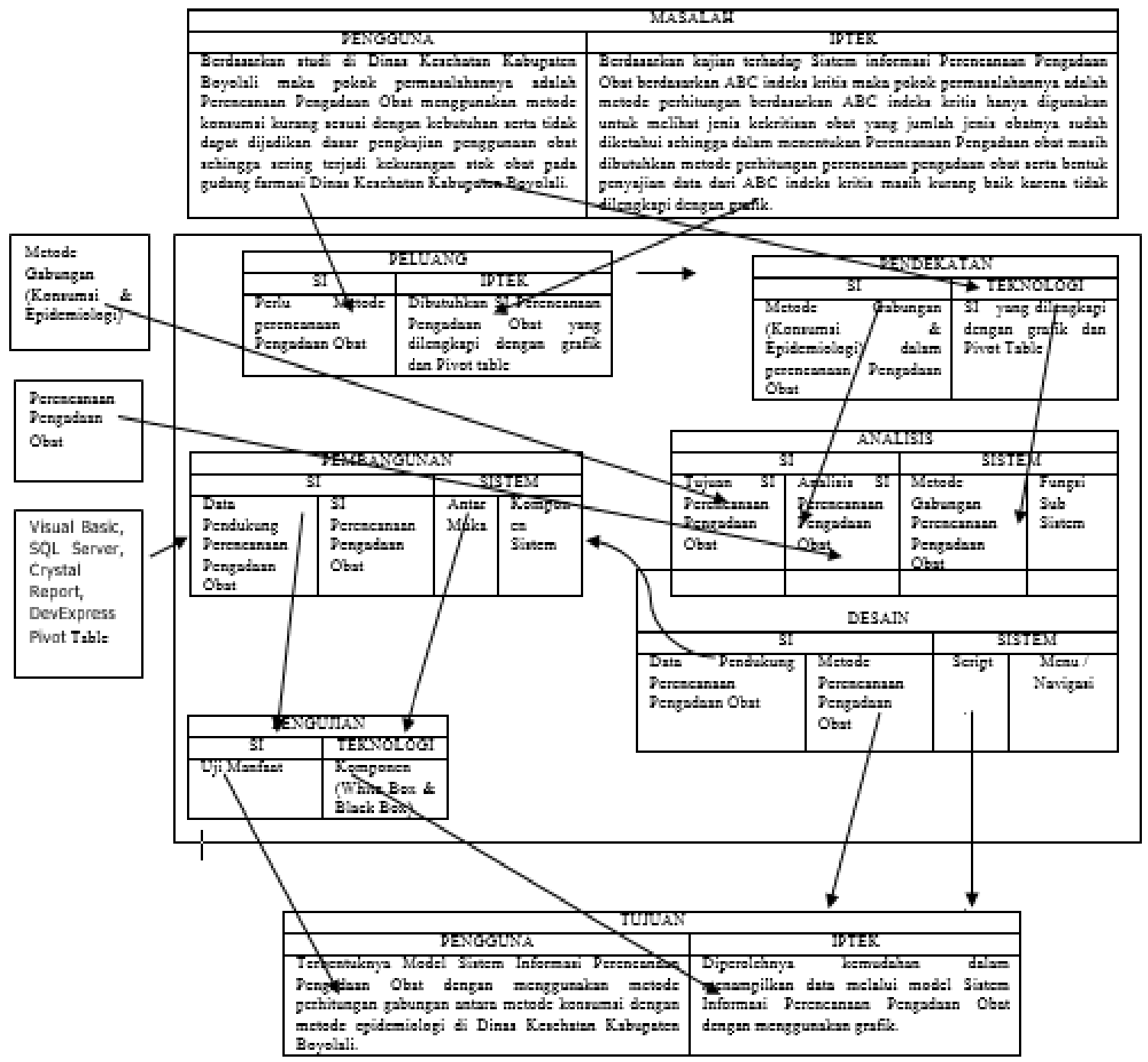

Gambar 1. Diagram Alir Metode Penelitian 
IV.HASIL DAN PEMBAHASAN

Tampilan awal dari Sistem Informasi Kesehatan Kabupaten. Kota tampak seperti gambar berikut ini.

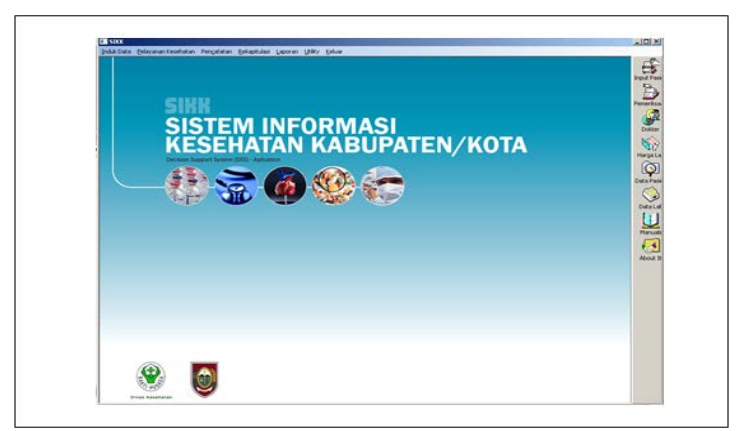

Gambar 2. Tampilan Awal

Salah satu fungsi sistem adalah Pelayanan Kesehatan (Umum, KIA, Imunisasi, Gigi, Laborat) seperti tampak pada gambar berikut.

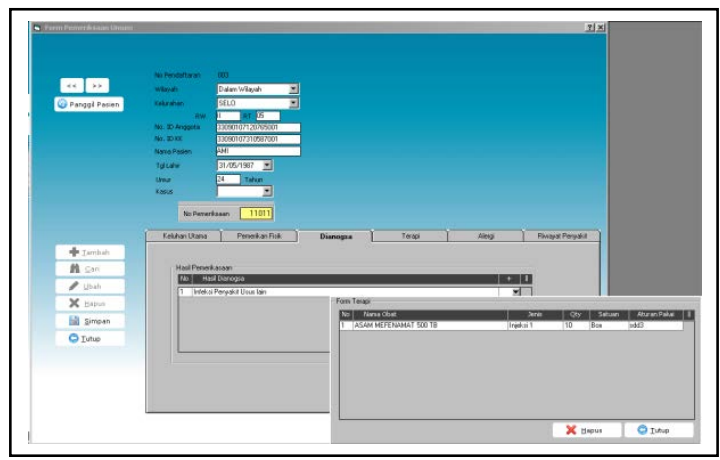

Gambar 3. Pelayanan Kesehatan (Umum, KIA, Imunisasi, Gigi, Laborat)

Untuk melakukan analisis perencanaan obat disediakan fungsi seperti berikut ini.

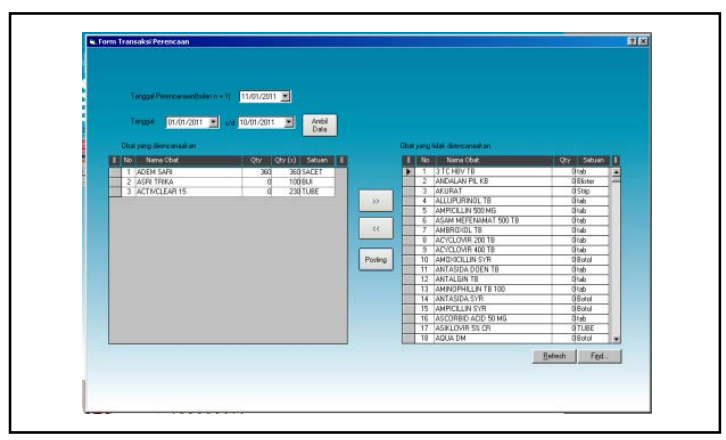

Gambar 4. Analisis Perencanaan Obat
Sistem yang dibangun telah berjalan sesuai dengan yang diharapkan baik fungsi- fungsi Input, Proses, maupun Output. Diantaranya adalah seperti berikut ini.

Input:

- Memasukkan keluhan pasien

- Memeriksa pasien

- Diagnosis penyakit pasien yang dilanjutkan dengan memasukkan obat yang digunakan untuk penyakit tersebut

Proses :

- Memasukkan diagnosis pasien dan obat yang digunakan serta jumlah obat yang diberikan kepada pasien ke dalam proses perencanaan pengadaan obat.

Output :

- Menggunakan Pivot Table untuk membuat laporan yang sesuai dengan yang diharapkan

- Menggunakan layar monitor untuk menampilkan hasil proses, untuk menyimpan data menggunakan media storage disk sedangkan untuk mencetak hasil menggunakan printer.

Sistem Informasi Perencanaan Pengadaan Obat dengan menggunakan pendekatan metode perhitungan gabungan antara metode konsumsi dengan metode epidemiologi di Dinas Kesehatan Kabupaten Boyolali telah berjalan sesuai dengan yang diharapkan.

\section{KESIMPULAN}

Kesimpulan yang dapat diambil dari penelitian ini adalah Sistem Informasi Perencanaan Pengadaan Obat Dinas Kesehatan Kabupaten telah berfungsi degnan baik sehingga diharapkan dapat membantu pemerintah daerah dalam mengambil keputusan untuk melakukan perencanaan pengadaan obat tahun berikutnya. 
Dengan menggunakan Sistem Informasi

Perencanaan Pengadaan Obat ini dapat diketahui jumlah obat yang direncanakan untuk dipesan secara efektif.

\section{REFERENSI}

[1] Quick, J.D., Rankin, J.R., Laing, R.O., O’Connor, R.W., Hogerzeil, H.V., Dukes, M.N.G., and Garnett, A (editors). Managing Drug Supply 2nd Edition. Kumarian Press. Connecticut. 1997.

[2] Departemen kesehatan RI. Pedoman Pengelolaan Obat Publik dan Perbekalan Kesehatan. Ditjen Pelayanan Kefarmasian dan Alat Kesehatan, Depkes RI. Jakarta. 2000 .

[3] Hamid, T.B.J. Elemen Pelayanan Minimum Farmasi di Rumah Sakit, Direktorat Jendral Pelayanan Kefarmasian dan Alat Kesehatan, Depertemen Kesehatan RI, diambil dari HTTP:// www.yanfar.go.id. Tanggal 10 Juni 2005.

[4] Arnawilis. Proses Perencanaan Obat di Rumah Sakit "Ibnu Sina” Yarsi Riau - Pekan Baru Tahun 2000. Program Pascasarjana Fakultas Kesehatan Masyarakat Universitas Indonesia. Depok. 2001.
[5] Anief, M. Manajemen Farmasi. Gadjah Mada University Press. Yogyakarta. 1995.

[6] Attawell $\mathrm{K}$ ed. Medical supplies and equipment for primary health care, A practical resource for procurement and management, ECHO International Health Services Ltd Ullswater Crescent. Coulsdon UK. 2001.

[7] Departemen Kesehatan Republik Indonesia. Sistem kesehatan Nasional. Depkes RI, Jakarta. 2004.

[8] Direktur Jendral Bina Kefarmasian dan Pelayanan Farmasi. Kebijakan Obat Nasional (KONAS). (Online). HTTP://www.litbang.depkes.go.id/download/lokakarya/ Bandung/Konas-Obat.pdf, diakses tanggal 18 Maret 2008.

[9] Suryawati Sri. Efisiensi Pengelolaan Obat di Rumah Sakit [Tesis]. Yogyakarta : Magister Manajemen Rumah Sakit Universitas Gajah Mada. 1997.

[10] LaFond A, Fields, R. The Prism: Introducing an Analytical Framework for Understanding Performance of Routine Health Information Systems in Developing Countries. In Second International RHINO Workshop on: Enhancing the Quality and Use of Routine Health Information at District Level. South Africa. 2003.

[11] Syamsi, I. Pengambilan Keputusan dan Sistem Informasi. Bumi Aksara. Jakarta. 1995. 